\title{
Eleonora Jedlińska, Powszechna Wystawa Światowa w Paryżu w 1900 roku. Splendory Trzeciej Republiki, Wyd. Uniwersytetu Łódzkiego, Łódź 2015, ss. 250.
}

Paris n'est pas une ville, c'est un monde. To popularne swego czasu powiedzonko doskonale ilustruje sposób, w jaki przez wiele dziesięcioleci patrzono na Paryż, nadając mu rangę centrum cywilizowanego świata. Tak postrzegany przez znaczną część Francuzów, jak i cudzoziemców, wyznaczał trendy $\mathrm{w}$ kulturze, sztuce, modzie, również przez wiele lat $w$ nauce czy technice, choć tu musiał niechętnie ustępować często miejsca odwiecznej angielskiej rywalce. W tym kontekście organizowane od roku 1851 Powszechne Wystawy Światowe stawały się forum szczególnym, forum prezentującym osiągnięcia cywilizacyjne poszczególnych krajów, jak i miejscem cichej rywalizacji między nimi o palmę pierwszeństwa pośród tych, które na owej cywilizacyjnej drabinie stoją najwyżej. Książka Eleonory Jedlińskiej, nawiązując do obu tych aspektów, stara się przybliżyć czytelnikom jedną z paryskich wystaw powszechnych - wystawę szczególną bo odbywającą się w 1900 r., na przełomie dwóch wieków. Wystawę traktowaną jako symboliczne wejście $\mathrm{w}$ nowa bardziej technologicznie zaawansowana, jeszcze bardziej nowoczesną epokę wieku $X X$, a także podsumowanie i zamknięcie rewolucjonizującego $\mathrm{w}$ wielu dziedzinach życie ludzi wieku XIX.

Wystawy powszechne to zjawisko samo w sobie interesujące, pokazujące nie tylko rozwój przemysłu czy nauki, ale też sposób, w jaki ludzie odnajdowali się w nowej, industrialnej rzeczywistości, $\mathrm{w}$ jaki ją rozumieli, jakie budziła nadzieje, ale też jakie lęki i zagrożenia. Z tego punktu widzenia wystawa roku 1900 zasługuje z pewnością na szczególną uwagę, wspartą dodatkowo powszechnym przywiązaniem do symbolicznego znaczenia tegoż roku postrzeganego przez współczesnych jako zamknięcie starego i otwarcie nowego wieku, co skłaniało do podsumowań i refleksji. $\mathrm{Z}$ tego też punktu widzenia podjęty przez E. Jedlińską projekt przybliżenia czytelnikowi owej wystawy wydaje się i zasadny, i interesujący, tym bardziej, że nie ma $\mathrm{w}$ zasadzie $\mathrm{w}$ języku polskim monografii poświęconej tejże wystawie, podobnie zresztą jak innym, pomijając wydawnictwa z epoki i prace odnoszace się do wybranych aspektów.

Tytuł książki Eleonory Jedlińskiej budzi w czytelniku zainteresowanym zarówno Francją jak i szeroko pojętym XIX wiekiem wielkie nadzieje, zwłaszcza jeżeli zwróci on baczniejszą uwagę na podtytuł książki: Splendory Trzeciej Republiki. Zdaje się on zapowiedzią opowieści o wystawie powszechnej, a jednocześnie podjęciem wątku znaczenia tej wystawy (i zapewne też innych) dla wzmocnienia pozycji państwa-organizatora, budowania i propagowania jego mocarstwowego wizerunku.

Już jednak w pierwszych zdaniach odautorskiego wprowadzenia czytelnik dowiaduje się, że książka dotyczyć ma w zasadzie jedynie wąskiego wycinka prezentowanej na wystawie rzeczywistości - architektury i sztuk pięknych. Poprzez pryzmat owych prezentowanych na wystawie dziedzin Autorka podejmuje się ambitnego zadania poszukania odpowiedzi na ważne pytanie, kiedy mianowicie optymizm, wiara w nieskończone możliwości naukowego wyjaśnienia świata, wiara $\mathrm{w}$ to, że świat zmienia się zawsze $\mathrm{w}$ stronę postępu (zmiana jest zawsze krokiem do przodu), przekształca się w niepewność, niepokój, zwątpienie $\mathrm{w}$ to, że droga do szczęścia i dobrobytu jest jasna, wytyczona i prowadzi poprzez rozwój nauki i techniki. To 
pytanie niezwykle istotne dla zrozumienia zjawisk w sztuce czy filozofii przełomu XIX i XX wieku, również dla zrozumienia mentalności ludzi belle époque. Jak pisze Autorka (s. 7), „zamiarem moim było zarysowanie - na tle spektaklu, jakim była wystawa 1900 roku - nurtujących ówczesne społeczeństwo problemów związanych, $\mathrm{z}$ jednej strony, $\mathrm{z}$ głębokim poczuciem uczestnictwa $\mathrm{w}$ wielkich przemianach historycznych, kulturowych, artystycznych i obyczajowych, a drugiej zaś - ze świadomością że czas «niewinności» nieuchronnie się kończy, że nadciąga «wielka katastrofa»".

Owo interesujące i ambitne zadanie nie zostaje jednak zrealizowane na kartach książki. Zarówno ograniczenie tematyczne, jak i sposób prezentacji wybranych zagadnień rozczarowują czytelnika, który wziął do ręki książkę zaintrygowany jej tytułem. Nieadekwatność tytułu do treści pracy zostaje przez Autorkę zapowiedziana i wyjaśniona na jej pierwszych stronach, co można uznać za wystarczające uprzedzenie czytelnika o tym, czego może, a czego nie może spodziewać się po dalszej lekturze. Jednak nawet $\mathrm{w}$ tej okrojonej wersji nie do końca udaje się Autorce zrealizować swoje zamiary. Stawia ona przywołaną już tezę o poczuciu zbliżającej się katastrofy, wbrew czy obok triumfu nauki i postępu, oraz o szczególnym znaczeniu sztuki w budowaniu tożsamości narodowej, „widząc $\mathrm{w}$ niej jeden $\mathrm{z}$ najważniejszych elementów składających się na całość pojęcia szeroko rozumianej cywilizacji,, (s. 10-11). To też staje się dla Autorki powodem, dla którego patrzy na wystawę roku 1900 z punktu widzenia architektury i sztuki.

Książka składa się z trzech części, które, zgodnie $\mathrm{z}$ zasadą: od ogółu do szczegółu, prowadzą czytelnika od części poświęconej idei wystaw powszechnych (cz. I), poprzez charakterystykę wystawy roku 1900 (cz. II), aż po prezentację sztuk pięknych na tejże wystawie (cz. III). Całość poprzedza wprowadzenie mające $\mathrm{w}$ zamyśle nakreślić najważniejsze i związane z ideą wystaw i postępu cywilizacyjnego zjawiska charakteryzujące koniec XVIII oraz wiek XIX. Ten problemowy układ nie budzi zastrzeżeń i jako ze wszech miar uzasadniony w najlepszy z możliwych sposobów mógłby przeprowadzić czytelnika przez wywody Autorki, charakteryzując zarówno samą idee wystaw, jak i ukazując na tym tle specyfikę tej z $1900 \mathrm{r}$.

Autorka jednak zdaje się mieć zasadniczy problem z syntezowaniem informacji, tworzeniem pewnego ogólnego obrazu zawierającego najważniejsze dla danego zjawiska elementy i cechy, wyciąganiem wniosków z bardziej szczegółowych relacji. Jest to widoczne $\mathrm{w}$ różnym natężeniu i w różny sposób we wszystkich częściach pracy. Kłopot z pewnymi uogólnieniami i umiejętnością rysowania tła widoczny jest szczególnie we wprowadzeniu do pracy, które składa się z dość przypadkowo „pozlepianych" informacji, oraz w części I poświęconej samej idei wystaw. Miały one pokazać warunki, trendy, procesy, które towarzyszyły/wpływały na pojawienie się i realizację idei nowożytnych wystaw powszechnych, nie udało się jednak skonstruować spójnego, zawierającego najważniejsze informacje obrazu.

Nie do końca wiadomo, jakie procesy uznaje Autorka za najistotniejsze, ponieważ samo hasło rewolucji przemysłowej niewiele mówi o jej konsekwencjach, szczególnie społecznych, a stwierdzenie, że wraz z rewolucją "nastąpiły przemiany społeczne, polityczne i obyczajowe, które odmieniły obraz świata i los ludzi" (s. 18), jest nieprecyzyjne i bardzo ogólnikowe. Dość chaotycznie i przypadkowo mieszają się informacje o "pasji wynalazczości”, wiszącym moście nad cieśniną Menai, mechanicznych lalkach lubianych we Francji, z tymi o losie robotników wielkoprzemysłowych, pierwszych, krajowych wystawach przemysłowych organizowanych we Francji od 1798 r. czy ze szczegółowym biogramem Lavoisiera umieszczonym w przypisie. Nie tworzą one żadnego spójnego obrazu najważniejszych przemian 
gospodarczo-społecznych, a następnie politycznych, mentalnych, obyczajowych, wiązanych zwykle $\mathrm{z}$ pojęciem rewolucji przemysłowej. To zdumiewa tym bardziej, ze Autorka przywołuje Europe Normana Daviesa, który dokonał świetnej syntezy kluczowych dla tego procesu zjawisk i ich skutków.

Zdecydowanie lepiej udało się przybliżyć czytelnikowi w cz. I genezę oraz krótką historię wystaw powszechnych, wywodząc ich początek od politycznej i gospodarczej rywalizacji francusko-angielskiej oraz poszukiwania środków umożliwiających ekonomiczną ekspansję, co jest interesującą i niepozbawioną słuszności tezą (s. 25-26). Kilka słów na temat charakteru, najważniejszych budowli wystawowych, udziału w nich Polaków poświęca Autorka wystawom z 1851 r. (Londyn), 1873 r. (Wiedeń), 1893 r. (Chicago) oraz czterem paryskim z lat 1855, 1867, 1878, 1889. Zupełnie natomiast nie wyjaśnia, czym kierowała się, wybierając akurat te, a nie inne wystawy światowe. O ile uwzględnienie wszystkich wystaw paryskich daje się uzasadnić w kontekście tej z roku 1900, a wystawa z roku 1851 pojawiła się ze względów oczywistych jako pierwsza światowa, to uwzględnienie pozostałych, a pominięcie innych, jeśli chodzi o powody, pozostaje tajemnicą.

Interesujące natomiast i wnoszące wiele nowych informacji faktograficznych są dwie pozostałe części książki: II poświęcona ogólnie wystawie roku 1900 oraz III prezentująca dzieła sztuki eksponowane na wystawie. Można nawet odnieść wrażenie, że im bardziej szczegółowe i związane z historią sztuki problemy Autorka porusza, tym lepiej czuje się w omawianej materii i tym lepiej sobie $z$ nia, jako historyk sztuki właśnie, radzi. Część II mimo swoich walorów poznawczych (zaprezentowane zostały tu najważniejsze założenia oraz najważniejsze realizacje nadające charakter i styl wystawie z 1900 r., m.in. Rue des Nations, Grand i Petit Palais, most Aleksandra III), wprowadza jednak czytelnika w błąd swoim tytułem nawiązującym do tytułu całej książki: Powszechna wystawa w Paryżu w 1900 roku - splendory Trzeciej Republiki.

Wystawa Powszechna była ze względów oczywistych ogromnym przedsięwzięciem propagandowym, miała nie tylko podsumować osiągnięcia wieku XIX, pokazać najważniejsze wynalazki i zdobycze nauki, ale też, a może z punktu widzenia Francuzów przede wszystkim, ukazać wielkość samej Francji, dorobek III Republiki, tak na początku nieufnie przez monarchiczną Europę traktowanej, utrwalić mit Paryża jako najwspanialszego miasta świata. Ale część II książki Eleonory Jedlińskiej, mimo swojego tytułu, ani jednym $\mathrm{w}$ zasadzie słowem nie uzasadnia twierdzenia o wystawie światowej jako wydarzeniu mającym ukazać splendory Trzeciej Republiki Francuskiej. Ani w tym rozdziale, ani w żadnym innym miejscu nie pojawia się uzasadnienie tytułu rozdziału i tytułu całej książki. A szkoda, ponieważ Trzecia Republika (i nie tylko ona) mistrzowsko i konsekwentnie prowadziła, używając współczesnego wyrażenia, politykę wizerunkową i wszystkie paryskie wystawy stanowiły mocny punkt owych działań.

Natomiast niewątpliwą zaletą zarówno tej, jak i następnej części książki jest sięgnięcie przez Autorkę do licznych przekazów źródłowych: korespondencji prasowych, przewodników po wystawie, relacji i analiz uczestników i zwiedzających, wydanych w postaci książkowej tuż po zakończeniu wystawy, projektów i planów wystawowych zamieszczanych w "L'Architecture”. Baza źródłowa wraz $\mathrm{z}$ fragmentami poświęconymi sztukom pięknym na wystawie paryskiej (cz. III) to niewątpliwie najmocniejsza strona książki. Warte podkreślenia jest też wyeksponowanie przez Autorkę kontekstu narodowego wystawy jako jednego z najistotniejszych elementów definiujących społeczeństwa 2 poł. XIX wieku poprzez narodziny państw narodowych oraz silnych nacjonalizmów. 
Niestety, podobnie jak pozostałe rozdziały ten również nie zawiera niczego, co można byłoby uznać za panoramiczne, szersze spojrzenie na kwestię sztuki przełomu wieków czy jej obecności/roli na wystawach powszechnych (podrozdział Secesja czy fin de siècle (międzynarodowy styl końca wieku) wbrew tytułowi w ogóle tej roli nie spełnia). Otrzymujemy rzetelny, ułożony krajami katalog dzieł sztuki, które pojawiły się na wystawie, uzupełniony rozdziałami poświęconymi aspektowi narodowemu, przywołanej już i nieudanej próbie zdefiniowania sztuki przełomu wieków, wystawom sztuki organizowanym obok wystawy powszechnej oraz polskiej na niej obecności. I o ile baza źródłowa i ustalenia faktograficzne są cennym elementem książki, to jakiekolwiek szersze spojrzenie, uogólnienia płynące ze zgromadzonych interesujących, ale pojedynczych informacji, umiejętność wyciągania mniej lub bardziej oczywistych wniosków charakteryzujących opisywane procesy i zjawiska na poziomie innym niż faktograficzny - to jej największa ułomność.

W tym kontekście nieuporządkowana bibliografia, w której z mozołem trzeba oddzielać źródła od opracowań, niezręczności/pomyłki pojęciowe, faktograficzne czy językowe zdają się drugorzędne, chociaż stwierdzenie, że „do połowy XVIII wieku w filozofii politycznej Francji dominowała ideologia liberalno-demokratyczna" (s. 15), przyprawia o ból głowy. Podobnie zresztą jak użycie terminu cesarstwo austro-węgierskie (s. 45), podczas kiedy mamy albo monarchię austro-węgierska, albo Cesarstwo Austriackie i Królestwo Węgierskie, włoskie wojny wyzwoleńcze w 2 poł. XIX w. (s. 35), zdumiewająca konstatacja „wobec nieobecności Niemiec" przy jednoczesnym $\mathrm{w}$ tym samym zdaniu zawartym stwierdzeniu, że nie istniało (do 1871 r.) zjednoczone państwo niemieckie (s. 31), czy umiejscowienie sojuszu francusko-rosyjskiego na rok 1891 (s. 82), kiedy to tylko wymieniono noty dyplomatyczne, a konwencję wojskową podpisano 17 sierpnia 1892 r., ratyfikując ją dopiero 27 grudnia 1893 r. i 4 stycznia 1894 r.

Reasumując, czytelnik dostaje do ręki książkę, której temat niesie ze sobą ogromny potencjał badawczy dotyczący zarówno refleksji nad samymi wystawami powszechnymi, które z biegiem lat stały się „,jarmarkiem świata" jako odzwierciedlenie procesów społecznych, mentalnych, gospodarczych zachodzących w XIX w., jak i sensu oraz charakteru tej szczególnej wystawy przełomu wieków, która z założenia miała być podsumowaniem osiągnięć wieku kończącego się i wskazaniem kierunków rozwoju w wieku nadchodzącym. Poprzez pryzmat wystawy roku 1900 można byłoby przyjrzeć się z bliska wielu procesom, które odcisnęły swoje piętno zarówno na XIX, jak i na XX w., nawet jeżeli ograniczylibyśmy się wyłącznie do dziedzin, które w sposób szczególny Autorka wzięła na warsztat, czyli architektury i sztuki. Zamiast jednak tego otrzymujemy prosty opis, który w żaden sposób nie pomaga zrozumieć/poznać tego odległego już świata.

Nie udaje się Autorce również zrealizować postawionych samej sobie zdań, tj. udowodnić szczególnego znaczenia sztuki na wystawie roku 1900 oraz dominacji na niej atmosfery dekadencji, schyłku, przeczucia katastrofy, mimo dość szczegółowego, ale nieopatrzonego żadną refleksją i komentarzem opisu. Kilkakrotnie za to wspomniane zostaje $\mathrm{w}$ tekście, że dla współczesnych najistotniejszy był aspekt postępu, rozwoju przemysłu, nauki, pozytywnych i negatywnych tego skutków, generalnie triumfu umysłu ludzkiego nad otaczającym go światem. Również w faworyzowanej przez Autorkę dziedzinie sztuk pięknych nie widać $\mathrm{w}$ przedstawionym przez nią katalogu akcentów dekadencji i schyłku. Wyraźnie zaznacza ona obecność na wystawie sztuki akademickiej jako głównego i preferowanego nurtu, mimo silnej obecności sztuki wiązanej z secesja biegnącej zawsze obok nurtu oficjalnego. A sztuka akademicka dekadenckich 
zwątpień końca wieku w ogóle nie podejmowała....

Tajemnicą pozostaje również to, co Autorka miała na myśli, opatrując książkę podtytułem Splendory Trzeciej Republiki przy truizmie wyjściowego założenia, że wystawy powszechne i splendor państwa/ miasta organizatora to związek niemal konieczny. Nie zawiedzie się natomiast poszukiwacz informacji dotyczących obecności na wystawie roku 1900 sztuk pięknych czy założeń architektonicznych jej towarzyszących, a także tropiciel polskiej obecności w świecie sztuki w czasach, kiedy ta obecność nie była niczym oczywistym. Nie dając odpowiedzi na wiele pytań (z których część sama stawia), a dotyczących kierunków, skutków, kosztów cywilizacyjnego rozwoju, książka Eleonory Jedlińskiej pozwala czytelnikowi bazującemu na informacjach w niej zgromadzonych samodzielnie poszukać na nie odpowiedzi. I o ile nie przywiąże się on zbyt mocno do nadziei wzbudzonych tytułem książki, może wynieść z jej lektury umiarkowaną satysfakcję.

Małgorzata Nossowska Instytut Historii

UMCS 